\title{
Neoclerodane Diterpenoids from Ajuga taiwanensis
}

\author{
Yu-Yi CHAN \\ Department of Biotechnology, Southern Taiwan University of Technology; Tainan, Taiwan, R.O.C. \\ Received August 20, 2004; accepted October 14, 2004 \\ Phytochemical investigation of Ajuga taiwanensis resulted in the isolation of seven neoclerodane diterpenes, \\ four of which ajugalide-A (1), -B (2), -C (3), and -D (4), are new and the remaining three are known diterpenes, \\ ajugamacrin B (5), ajugapantin A (6), and ajugamarin $C 1$ (7). Their structures were elucidated in spectral and \\ chemical transformation studies.
}

Key words Ajuga taiwanensis; Labiatae; diterpene

Ajuga taiwanensis NAKAI ex MURATA belongs to genus Ajuga (Labiatae) and is mainly distributed in Taiwan, the Philippines, and Ryukyus. Various species of Ajuga have been used for the treatment of incised wounds, snakebite, abdominal pain, fever, sore throat, cold, and lung disease in Taiwanese folk medicine. ${ }^{1)}$ Species of Ajuga have been reported to contain various bioactive clerodane diterpenoids ${ }^{2-4)}$ phytoecdysteroids, ${ }^{5-7)}$ and iridoids. ${ }^{8-10)}$ A. taiwanensis is often used for the treatment of hepatitis and hepatoma in Taiwanese folk medicine. In continuing chemical studies on medicinal plants of Taiwan, we investigated the constituents of this plant, which resulted in the isolation of seven neo-clerodane diterpenoids. We report here the isolation and structural elucidation of four new neoclerodane diterpenes, ajugalide- $\mathrm{A},-\mathrm{B},-\mathrm{C}$, and $-\mathrm{D}$, using spectroscopic methods and in chemical transformation studies.

\section{Results and Discussion}

Ajugalide-A (1) was isolated as an optically active, white amorphous solid, $\mathrm{mp} 205-206^{\circ} \mathrm{C}$. The high-resolution fastatom bombardment mass spectrum (HR-FAB-MS) of 1 showed a pseudo molecular ion peak $\left([\mathrm{M}+\mathrm{H}]^{+}\right)$at $\mathrm{m} / \mathrm{z}$ 509.2389 , which is in agreement with the molecular formula $\mathrm{C}_{26} \mathrm{H}_{36} \mathrm{O}_{10}$. Its ${ }^{1} \mathrm{H}$ - and ${ }^{13} \mathrm{C}$-NMR spectra were closely related to those of known compounds $\mathbf{6}$ and $\mathbf{7}$, suggesting that $\mathbf{1}$ has a neo-clerodane structure corresponding to that of $\mathbf{6}$ except for the positions of four substituted groups, one hydroxyl group, and three acetyls. To confirm the structure of 1, twodimensional correlation spectroscopy (2D-COSY) and the long-range ${ }^{13} \mathrm{C}-{ }^{1} \mathrm{H}$ correlation in heteronuclear multiple bond correlation (HMBC) experiments were conducted. The ${ }^{3} J$ HMBC correlation of $\mathrm{H}-12$ at $\delta 5.80$ with the carbon signal at $\delta 169.5$ and of the H-6 signal at $\delta 4.68$ with carbon resonance at $\delta 169.9$ established the locations of two acetate groups at C-6 and C-12, respectively. By comparing the chemical shift of H-1 in compound 1 with those of known compounds 6 and 7, a hydroxyl group was placed at C-1 and hence the other acetate group was attached to C-19. Acetylation of $\mathbf{1}$ yielded a product that was identical in spectral data to ajugapantin A (6). Thus compound $\mathbf{1}$ was identified as a 1deacetyl derivative of ajugapantin A (6). ${ }^{11)}$ On the basis of the above data, the absolute structure of $\mathbf{1}$ was established to be $(12 S)-6 \alpha, 12,19$-triacetoxy-1 $\beta$-hydroxy-4,18-epoxyneoclerod-13(14)-en-15,16-olide.

Ajugalide-B (2) was obtained as an optically active, white amorphous solid. The HR-FAB-MS established the molecular formula for 2 to be $\mathrm{C}_{26} \mathrm{H}_{36} \mathrm{O}_{10}$, indicating it to be an iso- mer of $\mathbf{1}$. Comparison of the ${ }^{1} \mathrm{H}$ - and ${ }^{13} \mathrm{C}-\mathrm{NMR}$ spectral data of 2 with those of 1 revealed the same relative arrangements of carbons and protons except for $\mathrm{H}-12$ and $\mathrm{H}-1$, and $\mathrm{C}-12$ and $\mathrm{C}-1$. The resonances corresponding to $\mathrm{H}-1$ and $\mathrm{H}-12$ were shifted to $\delta 5.68$ and $\delta 4.72$ in $\mathbf{2}$ from $\delta 4.32$ and $\delta$ 5.80 in $\mathbf{1}$, respectively. Similarly, in comparing $\mathbf{1}$ with $\mathbf{2}$, the chemical shifts were changed for C-1 and C- 12 by +3.0 and $-3.4 \mathrm{ppm}$, respectively. These suggest that an acetate group in 2 was located at $\mathrm{C}-1$, and thus a hydroxyl group at $\mathrm{C}-12$. To confirm the proposed structure, COSY, HMQC, and HMBC experiments were conducted. Acetylation of 2 with acetic anhydride and pyridine at room temperature also gave ajugapantin A (6). ${ }^{11)}$ Thus 2 was defined as $(12 S)-1 \beta, 6 \alpha, 19$ triacetoxy-12-hydroxy-4,18-epoxyneoclerod-13(14)-en15,16-olide.

Ajugalide-C (3), an optically active, white amorphous solid, exhibited an $[\mathrm{M}+\mathrm{H}]^{+}$ion peak at $m / z 451$, corresponding to the molecular formula $\mathrm{C}_{24} \mathrm{H}_{34} \mathrm{O}_{8}$. The ${ }^{1} \mathrm{H}$ - and ${ }^{13} \mathrm{C}$ NMR spectra (Tables 1,2) resembled those of 1 and $\mathbf{2}$ except for $\mathrm{H}-1$ and $\mathrm{C}-1$ signals, indicating that the structural difference resided only in the A-ring of the neoclerodane skeleton. The absence of the 1-hydroxyl function was evidenced by the disappearance of a ddd signal corresponding to $\mathrm{H}-1 \alpha[2$ at $\delta$ $5.68(1 \mathrm{H}, \mathrm{ddd}, J=10.8,10.8,4.8 \mathrm{~Hz})]$, existence of two multipliers for $\mathrm{H}-1$, and the change in the $\mathrm{H}-10$ signal from the doublet to a doublet of a doublet. This was further confirmed

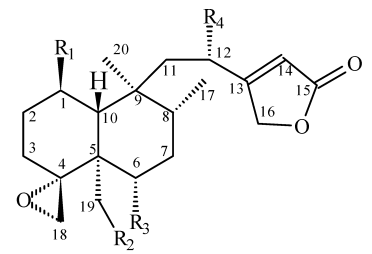

$$
\begin{array}{llll}
\mathrm{R}_{1} & \mathrm{R}_{2} & \mathrm{R}_{3} & \mathrm{R}_{4} \\
\mathrm{OH} & \mathrm{OAc} & \mathrm{OAc} & \mathrm{OAc} \\
\mathrm{OAc} & \mathrm{OAc} & \mathrm{OAc} & \mathrm{OH} \\
\mathrm{H} & \mathrm{OAc} & \mathrm{OAc} & \mathrm{OH} \\
\mathrm{OAc} & \mathrm{OAc} & \mathrm{OAc} & \mathrm{OCOCH}\left(\mathrm{CH}_{3}\right) \mathrm{CH}_{2} \mathrm{CH}_{3} \\
\mathrm{OAc} & \mathrm{OAc} & \mathrm{OAc} & \mathrm{OAc} \\
\mathrm{OH} & \mathrm{OAc} & \mathrm{OAc} & \mathrm{OH}
\end{array}
$$

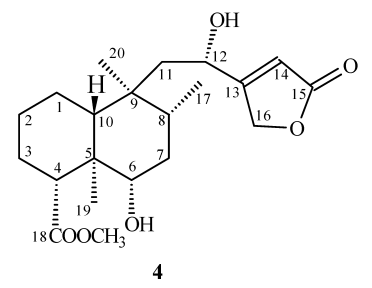


Table 1. ${ }^{1} \mathrm{H}$-NMR Spectral Data ${ }^{a)}$ of Compounds $\mathbf{1}-\mathbf{4 , 6}$ and $\mathbf{7}$

\begin{tabular}{|c|c|c|c|c|c|c|}
\hline & 1 & 2 & 3 & 4 & 6 & 7 \\
\hline \multirow[t]{2}{*}{1} & 4.32 ddd & 5.68 ddd & $1.70-1.50$ & $1.80-1.50$ & 5.50 ddd & 4.37 br dd \\
\hline & $(10.4,10.4,4.8)$ & $(10.8,10.8,4.8)$ & $1.26 \mathrm{~m}$ & $1.47 \mathrm{~m}$ & $(10.8,10.8,4.4)$ & $(10.6,10.6)$ \\
\hline \multirow[t]{3}{*}{2} & 2.20 dddd & 2.23 br d & $1.70-1.50$ & $1.80-1.50$ & 2.21 dddd & 2.20 br d $(12.8, \alpha)$ \\
\hline & $(12.8,4.8,4.8,2.0, \alpha)$ & $(10.8, \alpha)$ & & & $(12.8,4.8,4.8,2.4, \alpha)$ & \\
\hline & $1.70-1.40(\beta)$ & $1.63-1.56(\beta)$ & & & $1.80-1.40(\beta)$ & $1.70-1.55(\beta)$ \\
\hline \multirow[t]{4}{*}{3} & 2.27 dddd & 2.39 dddd & 2.14 br dd & $1.84 \mathrm{~m}(\alpha)$ & 2.37 dddd & $2.27 \mathrm{br} \mathrm{dd}$ \\
\hline & $(14.0,14.0,4.8,2.0, \alpha)$ & $(10.8,10.8,4.0,2.0, \alpha)$ & $(12.8,12.8, \alpha)$ & & $(11.2,11.2,4.8,2.8, \alpha)$ & $(14.0,14.0, \alpha)$ \\
\hline & $1.15 \mathrm{ddd}$ & $1.15 \mathrm{ddd}$ & $1.05 \mathrm{ddd}$ & $1.33 \mathrm{~m}(\beta)$ & $1.13 \mathrm{ddd}$ & 1.12 br dd \\
\hline & $(14.0,4.8,2.0, \beta)$ & $(10.8,2.8,2.8, \beta)$ & $(12.8,2.4,2.4, \beta)$ & & $(11.2,4.8,2.4, \beta)$ & $(14.0,4.8, \beta)$ \\
\hline 4 & & & & $2.16 \mathrm{dd}(12.4,3.2)$ & & \\
\hline 6 & $4.68 \mathrm{dd}(11.4,4.6)$ & $4.75 \mathrm{dd}(11.6,4.8)$ & $4.76 \mathrm{~m}$ & $3.54 \mathrm{dd}(11.2,4.4)$ & $4.68 \mathrm{dd}(10.8,4.0)$ & 4.72 dd $(12.4,4.7)$ \\
\hline \multirow[t]{4}{*}{7} & $1.70-1.40$ & $1.70 \mathrm{ddd}$ & $1.70-1.50$ & $1.80-1.50$ & $1.80-1.40$ & 1.70 ddd \\
\hline & & $(11.2,11.2,4.8, \alpha)$ & & & & $(12.4,12.4,12.4, \alpha)$ \\
\hline & & $1.63-1.56(\beta)$ & & & & $1.56 \mathrm{ddd}$ \\
\hline & & & & & & $(12.4,4.7,4.7, \beta)$ \\
\hline 8 & $1.70-1.40(\beta)$ & $1.88 \mathrm{~m}(\beta)$ & $1.70-1.50$ & $1.80-1.50$ & $1.80-1.40(\beta)$ & $1.83 \mathrm{~m}$ \\
\hline 10 & $1.70-1.40$ & $2.54 \mathrm{~d}(10.8)$ & $1.93 \mathrm{dd}(10.4,2.0)$ & $1.38 \mathrm{dd}(10.8,1.6)$ & $2.15 \mathrm{~d}(10.8)$ & $2.16 \mathrm{~d}(10.6)$ \\
\hline \multirow[t]{2}{*}{11} & $2.52 \mathrm{dd}(16.0,9.6)$ & $2.02 \mathrm{dd}(17.2,11.2)$ & $\begin{array}{l}1.95 \mathrm{dd} \\
(15.6,11.2)\end{array}$ & $1.88 \mathrm{dd}(15.6,8.8)$ & 2.52 dd $(16.0,8.0)$ & $2.65 \mathrm{dd}(15.9,10.4)$ \\
\hline & $1.82 \mathrm{~d}(16.0)$ & $1.72 \mathrm{~d}(17.2)$ & $1.45 \mathrm{~d}(15.6)$ & $1.45 \mathrm{~d}(15.6)$ & $1.80-1.40$ & $1.59 \mathrm{~d}(15.9)$ \\
\hline 12 & 5.80 br d $(9.6)$ & 4.72 brd (11.2) & 4.77 br d (11.2) & 4.74 br d (8.8) & 5.85 br d $(6.0)$ & 4.73 br d (10.4) \\
\hline 14 & $5.89 \mathrm{t}(1.8)$ & $5.94 \mathrm{t}(1.6)$ & $5.95 \mathrm{t}(1.3)$ & $5.94 \mathrm{t}(2.0)$ & $5.96 \mathrm{t}(1.6)$ & $5.87 \mathrm{t}(1.6)$ \\
\hline \multirow[t]{2}{*}{16} & $4.80 \mathrm{dd}(17.8,1.8)$ & $4.85 \mathrm{~d}(1.6)$ & $4.84 \mathrm{~d}(1.3)$ & $4.89 \mathrm{dd}(17.8,2.0)$ & $4.84 \mathrm{dd}(16.0,1.6)$ & $4.86 \mathrm{dd}(1.6)$ \\
\hline & $4.73 \mathrm{dd}(17.8,1.8)$ & & & $4.83 \mathrm{dd}(17.8,2.0)$ & $4.75 \mathrm{dd}(16.0,1.6)$ & \\
\hline 17 & $0.91 \mathrm{~d}(6.4)$ & $0.86 \mathrm{~d}(6.4)$ & $0.82 \mathrm{~d}(6.0)$ & $0.82 \mathrm{~d}(6.8)$ & $0.83 \mathrm{~d}(6.0)$ & $0.85 \mathrm{~d}(6.6)$ \\
\hline \multirow[t]{2}{*}{18} & $2.98 \mathrm{dd}(3.6,2.0)$ & $3.07 \mathrm{dd}(3.6,2.4)$ & $2.97 \mathrm{dd}(4.0,2.3)$ & & $3.02 \mathrm{dd}(4.0,1.2)$ & $3.01 \mathrm{dd}(3.8,2.0)$ \\
\hline & $2.26 \mathrm{~d}(3.6)$ & $2.32 \mathrm{~d}(3.6)$ & $2.21 \mathrm{~d}(4.0)$ & & $2.29 \mathrm{~d}(4.0)$ & $2.27 \mathrm{~d}(3.8)$ \\
\hline \multirow[t]{2}{*}{19} & $4.88 \mathrm{~d}(12.4)$ & $4.90 \mathrm{~d}(12.8)$ & $4.84 \mathrm{~d}(12.0)$ & $1.11 \mathrm{~s}$ & $4.93 \mathrm{~d}(12.8)$ & $4.87 \mathrm{~d}(12.6)$ \\
\hline & $4.31 \mathrm{~d}(12.4)$ & $4.41 \mathrm{~d}(12.8)$ & $4.39 \mathrm{~d}(12.0)$ & & $4.37 \mathrm{~d}(12.8)$ & $4.32 \mathrm{~d}(12.6)$ \\
\hline 20 & $0.89 \mathrm{~s}$ & $0.83 \mathrm{~s}$ & $0.75 \mathrm{~s}$ & $0.74 \mathrm{~s}$ & $0.75 \mathrm{~s}$ & $0.92 \mathrm{~s}$ \\
\hline \multirow[t]{3}{*}{ Ac } & $2.13 \mathrm{~s}$ & $2.14 \mathrm{~s}$ & $2.11 \mathrm{~s}$ & & $2.13 \mathrm{~s}$ & $2.10 \mathrm{~s}$ \\
\hline & $2.10 \mathrm{~s}$ & $2.09 \mathrm{~s}$ & $1.96 \mathrm{~s}$ & & $2.11 \mathrm{~s}$ & $1.95 \mathrm{~s}$ \\
\hline & $1.95 \mathrm{~s}$ & $1.96 \mathrm{~s}$ & & & $2.07 \mathrm{~s}$ & \\
\hline \multicolumn{2}{|c|}{$\mathrm{OH}$} & 3.45 br s & & & $1.95 \mathrm{~s}$ & \\
\hline \multicolumn{2}{|c|}{$\mathrm{COOCH}_{3}$} & & & $3.63 \mathrm{~s}$ & & \\
\hline
\end{tabular}

a) Spectral data were obtained in $\mathrm{CDCl}_{3}$ at $400 \mathrm{MHz}$. Chemical shift are given in $\delta$ values.

by a new methylene carbon signal instead of the methine carbon assigned at $\mathrm{C}-1$ in 2 and an upfield shift of $\mathrm{C}-10$ by $2 \mathrm{ppm}$ in the ${ }^{13} \mathrm{C}$-NMR spectrum. The presence of two acetyl groups was inferred by the ${ }^{1} \mathrm{H}-\mathrm{NMR}$ signals at $\delta 2.11$ and 1.96 together with carbon signals at $\delta 171.0$ (s), 170.2 (s), 21.2 (q), and 21.2 (q). By comparing the chemical shift of H12 and $\mathrm{C}-12$ with those of compounds $\mathbf{1}$ and $\mathbf{2}$, the acetate groups were attached at C-6 and C-19. The complete assignments were established using ${ }^{1} \mathrm{H}-{ }^{1} \mathrm{H}$ COSY, HMQC, and HMBC experiments. The absent coupling of $\mathrm{H}-12$ with $\mathrm{H}-$ $11 \mathrm{~b}$ and vicinal coupling between $\mathrm{H}-12$ and $\mathrm{H}-11 \mathrm{a}$ are consistent with the staggered conformation with $c a .90^{\circ}$ and $c a$. $150^{\circ}$ dihedral angles between the protons. The NOEs between $\mathrm{H}-17$ and $\mathrm{H}-12$, between $\mathrm{H}-17$ and $\mathrm{H}-11 \mathrm{~b}$, and between $\mathrm{H}-12$ and $\mathrm{H}-8 \beta$, combined with the above conformation, revealed the configuration at $\mathrm{C}-12$ to be as depicted in Fig. 1. Consequently, the structure of ajugalide- $\mathrm{C}$ was elucidated to be (12S)-6 $\alpha, 19$-diacetoxy-12-hydroxy-4,18-epoxyneoclerod-13(14)-en-15,16-olide.

Ajugalide-D (4) was obtained as a white amorphous solid, and the molecular formula was determined to be $\mathrm{C}_{21} \mathrm{H}_{32} \mathrm{O}_{6}$ in HR-FAB-MS. The ${ }^{13} \mathrm{C}-\mathrm{NMR}$ spectrum of $\mathbf{4}$ showed five quarternary carbons, six methines, six methylenes, and four methyls (Table 1). The ${ }^{1} \mathrm{H}-\mathrm{NMR}$ spectrum displayed an $\alpha, \beta$ unsaturated $\gamma$-lactone group bearing an $\alpha$-hydrogen atom at $\delta 5.94(1 \mathrm{H}, \mathrm{d}, J=2.0 \mathrm{~Hz}), 4.89(1 \mathrm{H}, \mathrm{dd}, J=17.8,2.0 \mathrm{~Hz})$, and
$4.83(1 \mathrm{H}, \mathrm{dd}, J=17.8,2.0 \mathrm{~Hz})$, which was also indicated by the IR bands at $1777(\mathrm{C}=\mathrm{O}), 1632(\mathrm{C}=\mathrm{C}) \mathrm{cm}^{-1}$ and the UV absorption at $212 \mathrm{~nm}$. ${ }^{1} \mathrm{H}$ - and ${ }^{13} \mathrm{C}$-NMR complete assignments made using a combination of ${ }^{1} \mathrm{H}-{ }^{1} \mathrm{H}$ COSY, HMQC, and $\mathrm{HMBC}$ spectra revealed that $\mathbf{4}$ possesses a tricyclic neoclerodane structure similar to that of ajugalide-C (3), but differed in substitution. The presence of a methyl carboylate group was evidenced by signals at $\delta 3.63(3 \mathrm{H}, \mathrm{s})$ together with ${ }^{13} \mathrm{C}$-NMR signals at $\delta 176.9$ (s) and $51.6(\mathrm{q})$. This was placed at $\mathrm{C}-4$ instead of the oxirane ring in $\mathbf{1}-\mathbf{3}$ based on a doublet of a doublet at $\delta 2.16$ assignable to $\mathrm{H}-4$ and its HMBC correlations to $\mathrm{C}-5$ and $\mathrm{C}-18$. An extra methyl group at $\delta 1.11$ was connected to $\mathrm{C}-5$ as it showed HMBC cross peaks with C-4, C-5, C-6, and C-10. An upfield shift of H-6 to $\delta 3.54$ and downfield shift of C-6 to $\delta 77.9$ indicated that C-6 was hydroxylated. The relative stereochemistries of H-4, $\mathrm{H}-6$, and H-10 were also deduced to be in the axial orientation from the 12.4-, 11.2-, and 10.8- $\mathrm{Hz}$ coupling constants between $\mathrm{H}-4$ and $\mathrm{H}-3, \mathrm{H}-6$ and $\mathrm{H}-7$, and $\mathrm{H}-10$ and $\mathrm{H}-1$, respectively. Moreover, the NOE correlations of H-4 with H-6 and $\mathrm{H}-10$, and of H-8 with H-6 and H-10, indicated the cisconfiguration. The configuration of $\mathrm{H}-10$ with the methyl group at C-5 was determined to be trans due to the absence of a NOE cross peak between H-10 $(\delta$ 1.38) and H-19 $(\delta$ 1.11 ) in the NOESY experiment. On the other hand, the configuration of methyl groups at C-5 with C-9 was determined 
Table 2. ${ }^{13} \mathrm{C}$-NMR Spectral Data ${ }^{a)}$ of Compounds 1, 2, 3, 4, 6 and 7

\begin{tabular}{|c|c|c|c|c|c|c|}
\hline Compound & 1 & 2 & 3 & 4 & 6 & 7 \\
\hline 1 & 68.7 & 71.7 & 21.6 & 21.4 & 70.7 & 69.0 \\
\hline 2 & 36.9 & 31.9 & 32.9 & 25.6 & 31.9 & 36.3 \\
\hline 3 & 30.6 & 30.3 & 32.7 & 25.6 & 30.5 & 30.6 \\
\hline 4 & 64.3 & 64.1 & 65.1 & 56.0 & 64.3 & 64.3 \\
\hline 5 & 45.6 & 50.0 & 45.5 & 44.4 & 46.1 & 45.7 \\
\hline 6 & 71.4 & 71.4 & 72.3 & 77.9 & 71.4 & 71.6 \\
\hline 7 & 32.8 & 32.8 & 24.7 & 36.2 & 32.8 & 33.0 \\
\hline 8 & 38.5 & 35.0 & 35.3 & 35.7 & 35.5 & 35.2 \\
\hline 9 & 39.3 & 39.3 & 39.4 & 39.6 & 39.2 & 39.4 \\
\hline 10 & 56.5 & 50.8 & 49.0 & 49.5 & 50.4 & 52.2 \\
\hline 11 & 43.3 & 43.9 & 43.0 & 43.8 & 41.8 & 43.9 \\
\hline 12 & 68.9 & 65.5 & 65.3 & 65.4 & 66.5 & 65.0 \\
\hline 13 & 169.0 & 173.1 & 173.0 & 173.5 & 168.7 & 175.2 \\
\hline 14 & 115.8 & 114.5 & 114.7 & 114.5 & 116.3 & 113.8 \\
\hline 15 & 172.6 & 173.7 & 173.2 & 172.9 & 172.6 & 174.1 \\
\hline 16 & 70.8 & 71.0 & 70.6 & 70.7 & 70.7 & 71.2 \\
\hline 17 & 13.8 & 15.5 & 15.4 & 15.7 & 15.8 & 15.5 \\
\hline 18 & 48.3 & 49.2 & 48.4 & 176.9 & 48.8 & 48.7 \\
\hline 19 & 61.5 & 62.1 & 61.7 & 9.4 & 61.6 & 61.7 \\
\hline 20 & 15.6 & 17.4 & 17.2 & 17.4 & 17.1 & 17.2 \\
\hline \multirow[t]{8}{*}{ Ac } & 170.6 & 170.3 & 171.0 & & 170.6 & 170.7 \\
\hline & 169.9 & 169.9 & 170.2 & & 170.0 & 170.1 \\
\hline & 169.5 & 167.9 & 21.2 & & 169.6 & 21.2 \\
\hline & 21.1 & 22.0 & 21.2 & & 169.6 & 21.2 \\
\hline & 21.1 & 21.1 & & & 22.0 & \\
\hline & 21.1 & 21.1 & & & 21.4 & \\
\hline & & & & & 21.3 & \\
\hline & & & & & 21.3 & \\
\hline $\mathrm{OCH}_{3}$ & & & & 51.6 & & \\
\hline
\end{tabular}

a) Spectral data were obtained in $\mathrm{CDCl}_{3}$ at $100 \mathrm{MHz}$. Chemical shift are given in $\delta$ values.

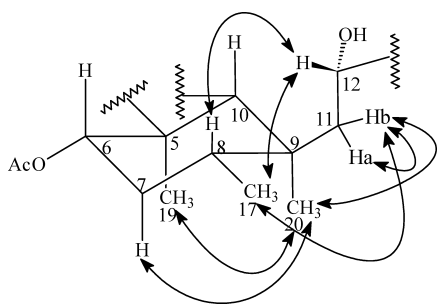

Fig. 1

to be $c i s$ due to the cross peak between $\mathrm{H}-19(\delta 1.11)$ and $\mathrm{H}-$ $20(\delta 0.74)$ in the NOESY experiment. Based on the above analyses, the structure of ajugalide-D (4) is (12S)methyl $6 \alpha, 12$-dihydroxy- $4 \alpha$-methoxycarbonyl-18-norneo-clerod13(14)-en-15,16-olide.

The known compounds ajugamacrin $\mathrm{B}(\mathbf{5}),{ }^{12)}$ ajugapantin $\mathrm{A}(\mathbf{6}),{ }^{11)}$ and ajugamarin $\mathrm{C} 1(7)^{11)}$ were identified and characterized by comparison of their spectroscopic data with the value reported in the literature.

\section{Experimental}

General Melting points were determined on a Yanagimoto MP-S3 apparatus and are uncorrected. Optical rotations were measured on a JASCO DIP-370 polarimeter. IR and UV spectra were recorded on Shimadzu FTIR8501 and Hitachi UV-3210 spectrophotometers, respectively. EIMS was obtained on a VG-70-250S mass spectrometer. The ${ }^{1} \mathrm{H}-$ and ${ }^{13} \mathrm{C}-\mathrm{NMR}$, DEPT, COSY, HMQC, NOESY, and HMBC experiments were recorded on a Bruker AMX-400 spectrometer.

Plant Material A. taiwanensis was collected from Tainan, Taiwan, in August 2001 and verified by Prof. C.-S. Kuoh. A voucher specimen (TSWu 90003) has been deposited in the Herbarium of National Cheng Kung University, Tainan, Taiwan.

Extraction and Separation The dried whole plants of $A$. taiwanensis
$(68 \mathrm{~g})$ were extracted with $\mathrm{MeOH}(\times 10)$ at room temperature and concentrated to give a dark brown syrup $(14.7 \mathrm{~g})$. The syrup was partitioned succesively between $\mathrm{H}_{2} \mathrm{O}$ and $\mathrm{CHCl}_{3}$. The $\mathrm{CHCl}_{3}$ layer $(3.4 \mathrm{~g})$ was chromatographed directly on silica gel and eluted with a gradient of $n$-hexane and EtOAc to afford 13 fractions. Fractions 6, 7, and 8 were combined, rechromatographed on silica gel, and eluted with $\mathrm{CHCl}_{3}-\mathrm{MeOH}(30: 1, \mathrm{v} / \mathrm{v})$ to give $5(56 \mathrm{mg})$. Fraction 10 underwent chromatography on silica gel using $\mathrm{CHCl}_{3}-\mathrm{MeOH}(15: 1, \mathrm{v} / \mathrm{v})$ as an eluent to afford $1(2 \mathrm{mg}), 2(5 \mathrm{mg}), 3$ $(1 \mathrm{mg}), \mathbf{4}(0.8 \mathrm{mg}), \mathbf{6}(8 \mathrm{mg})$, and $7(11 \mathrm{mg})$, successively.

Ajugalide-A (1): White amorphous solid, mp $205-206^{\circ} \mathrm{C} .[\alpha]_{\mathrm{D}}^{25}-6.2^{\circ}$ $\left(c=0.12, \mathrm{CHCl}_{3}\right)$. UV $\lambda_{\max }(\mathrm{MeOH}) \mathrm{nm}(\log \varepsilon): 212(3.51) . \mathrm{IR}(\mathrm{KBr}) \mathrm{cm}^{-1}$. 3498, 2970, 2934, 1780, 1743, 1732, 1637, 1449, 1373, 1232, 1161, 1095, 1032, 897, 754. ${ }^{1} \mathrm{H}$ - and ${ }^{13} \mathrm{C}-\mathrm{NMR}$ data, see Tables 1 and 2. FAB-MS $\mathrm{m} / \mathrm{z}$ : $509\left([\mathrm{M}+\mathrm{H}]^{+}, 49\right), 466(6), 450(4), 449$ (12), 391 (4), 329 (10), 311 (14), 201 (28), 185 (100). HR-FAB-MS $m / z$ : 509.2389 (Calcd for $\mathrm{C}_{26} \mathrm{H}_{37} \mathrm{O}_{10}$ : 509.2387).

Preparation of 6 from 1 Acetylation of ajugalide-A (1) with $\mathrm{Ac}_{2} \mathrm{O}$ and pyridine in the usual manner afforded the 1 -acetate $\mathbf{6}, \mathrm{mp} 200-202^{\circ} \mathrm{C}$. $[\alpha]_{\mathrm{D}}^{25}-20.8^{\circ}\left(c=0.04, \mathrm{CHCl}_{3}\right)$.

Ajugalide-B (2): White amorphous solid, mp $209-210^{\circ} \mathrm{C}$. $[\alpha]_{\mathrm{D}}^{25}+2.4^{\circ}$ $\left(c=0.27, \mathrm{CHCl}_{3}\right)$. UV $\lambda_{\max }(\mathrm{MeOH}) \mathrm{nm}(\log \varepsilon): 211(3.3)$. IR $(\mathrm{KBr}) \mathrm{cm}^{-1}$ : 3520, 2971, 2935, 1779, 1747, 1729, 1714, 1638, 1455, 1373, 1239, 1173, 1137, 1082, 1027, 900, 759. ${ }^{1} \mathrm{H}$ - and ${ }^{13} \mathrm{C}-\mathrm{NMR}$ data, see Tables 1 and 2. EIMS $m / z: 508$ ([M] $\left.{ }^{+}, 2\right), 478$ (46), 465 (32), 435 (51), 394 (24), 393 (100), 363 (30), 333 (39), 316 (22), 315 (43), 303 (56), 298 (22), 219 (20), 203 (25), 189 (89), 175 (45), 173 (57), 157 (45), 119 (47), 105 (51), 91 (54). HR-FAB-MS $m / z: 509.2389$ (Calcd for $\mathrm{C}_{26} \mathrm{H}_{37} \mathrm{O}_{10}: 509.2387$ ).

Ajugalide-C (3): White amorphous solid, $\mathrm{mp} 158-160^{\circ} \mathrm{C}$. $[\alpha]_{\mathrm{D}}^{25}-10.4^{\circ}$ $\left(c=0.07, \mathrm{CHCl}_{3}\right)$. UV $\lambda_{\text {max }}(\mathrm{MeOH}) \mathrm{nm}(\log \varepsilon): 211(3.2)$. IR $(\mathrm{KBr}) \mathrm{cm}^{-1}$ : 3446, 2937, 1776, 1744, 1733, 1637, 1460, 1373, 1250, 1151, 1030, 866, 756. ${ }^{1} \mathrm{H}$ - and ${ }^{13} \mathrm{C}-\mathrm{NMR}$ data, see Tables 1 and 2 . FAB-MS $\mathrm{m} / \mathrm{z}: 451$ $\left([\mathrm{M}+\mathrm{H}]^{+}, 11\right), 436$ (2), 408 (2), 391 (4), 331 (9), 203 (14), 180 (88), 135 (100). HR-FAB-MS $m / z$ : 451.2328 (Calcd for $\mathrm{C}_{24} \mathrm{H}_{35} \mathrm{O}_{8}: 451.2332$ ).

Ajugalide-D (4): White amorphous solid, $\mathrm{mp} 210-212^{\circ} \mathrm{C}$. $[\alpha]_{\mathrm{D}}^{25}-12.7^{\circ}$ $\left(c=0.05, \mathrm{CHCl}_{3}\right)$. UV $\lambda_{\max }(\mathrm{MeOH}) \mathrm{nm}(\log \varepsilon): 212(3.4)$. IR $(\mathrm{KBr}) \mathrm{cm}^{-1}$. $3448,2924,1777,1748,1632,1461,1379,1216,1149,1038 .{ }^{1} \mathrm{H}-$ and ${ }^{13} \mathrm{C}-$ NMR data, see Tables 1 and 2. FAB-MS $m / z: 381\left([\mathrm{M}+\mathrm{H}]^{+}, 53\right), 366(4)$, 
363 (94), 349 (17), 331 (12), 303 (56), 285 (17), 244 (17), 235 (82), 221 (21), 203 (27), 185 (100). HR-FAB-MS m/z: 403.2092 (Calcd for $\left.\mathrm{C}_{21} \mathrm{H}_{32} \mathrm{O}_{6} \mathrm{Na}: 403.2097\right)$.

Acknowledgments We thank the National Science Council, R.O.C. (NSC 90-2113-M-273-001) for financial support of this research and Prof. Chang Sheng Kuoh for the collection and identification of the plant material.

\section{References}

1) Hou D., "Flora of Taiwan," Vol. 4, Editorial Committee of the Flora of Taiwan, Taipei, Taiwan, 1996, p. 442.

2) Shimomura H., Coll J., Chem. Pharm. Bull., 37, 996-998 (1989).

3) Min Z. D., Wang S. Q., Zheng Q. T., Wu B., Mizuno M., Tanaka T., Iinuma M., Chem. Pharm. Bull., 37, 2505-2508 (1989).

4) Min Z. D., Mizuno M., Wang S. Q., Iinuma M., Tanaka T., Chem. Pharm. Bull., 38, 3167-3168 (1990).
5) Imai S., Toyosato T., Sakai M., Sato Y., Fujioka S., Murata E., Goto M., Chem. Pharm. Bull., 17, 340-342 (1969).

6) Koreeda M., Nakanishi K., Goto M., J. Am. Chem. Soc., 92, 75127513 (1970).

7) Camps F., Coll J., Phytochemistry, 32, 1361-1370 (1993).

8) Takeda Y., Tsuchida S., Fujita T., Phytochemistry, 26, 2303-2306 (1987).

9) Shimomura H., Sashida Y., Ogawa K., Phytochemistry, 26, 19811983 (1987).

10) Takasaki M., Yamauchi I., Haruna M., Konoshima T., J. Nat. Prod., 61, 1105-1109 (1998).

11) Shimomura H., Sashida Y., Ogawa K., Chem. Pharm. Bull., 37, 354357 (1989).

12) Shimomura H., Sashida Y., Ogawa K., Chem. Pharm. Bull., 37, 988992 (1989). 